International Journal of Health Sciences
Available online at www.sciencescholar.us
Vol. 5 No. 3, December 2021, pages: 594-604
e-ISSN: 2550-696X, p-ISSN: 2550-6978
https://doi.org/10.53730/ijhs.v5n3.2572

\title{
ICT Role during COVID-19 Pandemic in Lifelong Learning for Disabilities
}

\author{
(C) Crossmark \\ Natalia Savinova a, Mariya Berehova ${ }^{b}$, Kateryna Yanchytska c, Nina Stelmah ${ }^{\text {d }}$, Olena Biliuk ${ }^{\text {e, }}$ \\ Olena Kasatkina-Kubyshkina ${ }^{\mathrm{f}}$
}

Manuscript submitted: 18 July 2021, Manuscript revised: 16 October 2021, Accepted for publication: 24 November 2021

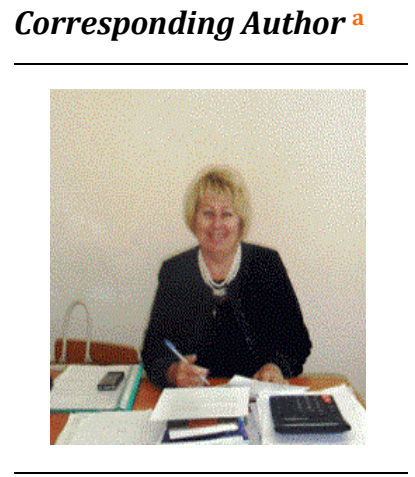

Keywords

COVID-19 pandemic;

education

informatization;

life-long education;

disabilities;

remote education;

healthy people;

\begin{abstract}
Education of people with disabilities requires special attention because data from world organizations show that only $5 \%$ of people with disabilities receive a quality basic education. This study seeks to determine the possibility of improving the education of people with special needs through the use of ICT technologies during the covid-19 pandemic in continuing education, that is, lifelong learning. Even though most studies focus on the possibility of using ICT in the education of children with disabilities and are subject to the formation of an inclusive digital space, the feasibility of using basic knowledge of people with disabilities during their profile education and self-development with the help of ICT through distance or blended life-long learning becomes relevant. A review of the literature on the problem of research shows that when ICTs are transformed due to the use of additional technical or software tools, people with disabilities have the opportunity to life-long learning, obtain a profession, develop in it and move up the career ladder. At the same time, ICTs can be used to learn foreign languages and acquire a whole range of knowledge in a distance or blended format.
\end{abstract}

International Journal of Health Sciences (C) 2021.

This is an open access article under the CC BY-NC-ND license (https://creativecommons.org/licenses/by-nc-nd/4.0/).

a V. O. Sukhomlynskyi National University of Mykolaiv, Kharkiv, Ukraine

b V. O. Sukhomlynskyi National University of Mykolaiv, Kharkiv, Ukraine

c Bogomolets National Medical University, Kyiv, Ukraine

d V. O. Sukhomlynskyi National University of Mykolaiv, Kharkiv, Ukraine

e V. O. Sukhomlynskyi National University of Mykolaiv, Kharkiv, Ukraine

f Rivne State University of the Humanities, Rivne, Ukraine 


\begin{tabular}{|c|c|c|}
\hline \multicolumn{3}{|c|}{ Contents } \\
\hline \multicolumn{3}{|c|}{ Abstract... } \\
\hline 1 & Introduction... & 595 \\
\hline 2 & Materials and Methods ……………………………..... & 596 \\
\hline 3 & Results and Discussions & 596 \\
\hline & 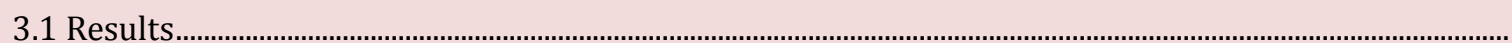 & 596 \\
\hline & 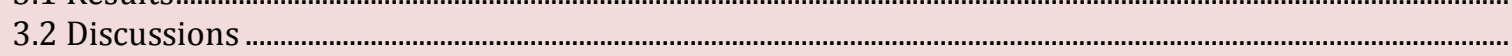 & 599 \\
\hline 4 & Conclusion ................... & 599 \\
\hline & Acknowledgments & 600 \\
\hline & References & 601 \\
\hline & uthors & 604 \\
\hline
\end{tabular}

\section{Introduction}

The rapid development of modern society and its constant transformation requires the training of highly qualified specialists in all leading sectors. A graduate of a modern school must possess a set of basic skills and abilities that are formed in parallel with the basic competencies. At the same time, the knowledge acquired in the course of basic education is practically accurate and allows him to not only adapt to the environment but also comfortably develop in it, acquiring the desired profession (Davydov, 2010). Of course, having received a vocational education, a person realizes himself in a particular profession, constantly improving his professional skills and knowledge, self-developing and improving throughout life. But what about those people whose physical or mental capabilities are limited? (Poroshenko, 2019). According to the World Health Organization, more than one billion people live with some form of disability. This figure is $15 \%$ of the entire population of the planet, of which 3.8\% account for people aged 15 years and older, and these are individuals who need the assistance of others because of significant health problems (WHO, 2020).

Data from the UNESCO World Organization confirms the fact that people with physical and mental disabilities are very unlikely to visit [UNESCO]. Experts estimate that only $5 \%$ of people with disabilities finish elementary school since general education programs are not adapted to the level that is available to children with special needs (Peters, 2003). And the United Nations Children's Fund (UNICEF) estimates that in lowincome countries $90 \%$ of children with disabilities will never receive basic education (UNICEF, 2014a).

The UNESCO database for 2019 notes that adults with disabilities are considered one of the most vulnerable segments of society. Due to the limited opportunity to attend general education institutions for general basic education, the level of literacy in adulthood is low, which does not allow them to obtain higher specialized education and to realize themselves in a certain profession (UNESCO, 2019).

In 2006, the UN adopted the Convention on the Rights of Persons with Disabilities. This convention clearly states that every child and every person with a developmental disability, as well as healthy people, has the right to quality basic education, and in 2016 adjustments were made about vocational education (UN Division).

At the present stage of development in the world there is no single model of education that could meet the needs and capabilities of all people with special needs, so the relevance of individual educational trajectory, which is based not only on taking into account the individual capabilities of people with special needs but also on the need to adapt educational programs to the level of these people (Kavcic, 2005). The solution to this problem is possible under two conditions, the first of which is the use of the electronic form of learning with the use of ICT, the second is the organization of life-long learning activities - continuous learning (Brahim et al., 2013).

Continuous learning is a dynamic process, which is defined and implemented taking into account the individual characteristics and needs of the applicant for education. Continuous learning is based on an individualized approach that takes into account the level of mental and physical capabilities of the individual who seeks to learn (Vuorikari et al., 2016). Continuous education is an active life-long learning activity of a person based on her desire for self-development and self-improvement (London, 2012). Life-long learning and continuing education contribute to the development of a learning society. A learning society is a vision of

Savinova, N., Berehova, M., Yanchytska, K., Stelmah, N., Biliuk, O., \& Kasatkina-Kubyshkina, O. (2021). ICT role during COVID-19 pandemic in lifelong learning for disabilities. International Journal of Health Sciences, 5(3), 594604. https://doi.org/10.53730/ijhs.v5n3.2572 
society that is based on the possibility of providing educational activities for everyone, wherever they are, whatever their age, no matter what their gender or level of physical or mental development (Laal, 2013).

Life-long learning is a form of learning that is suitable for absolutely everyone but people with disabilities. It is an opportunity to get not only basic education but also a professional one. Recently, people who live with disabilities are increasingly expressing a desire not only to improve their level of literacy but also to get a profession that could help them feed themselves, earn more (Díez-Palomar et al., 2021).

\section{Literature review}

The peculiarities of modern society informatization in their studies describe Bykov \& Ovcharuk (2017), Osadchyi \& Osadcha (2015), etc. The peculiarities of the country's information and digital environment formation were investigated by Hurevych et al. (2012), Piekhota et al. (2013), etc. Mechanisms and specifics of the introduction of ICTs in the educational space of institutions of general secondary education in their works described: peculiarities of the introduction of information and communication technologies in the educational process in institutions of general secondary education were studied by Bak (2014), Vorozhbyt (2018), Dyshlieva (2010), Shevchenko (2017), etc. Among the scientists who researched the forms of implementation of life-long learning were foreign scholars Beaton (2019), London (2012), Laal (2013), Hurevych et al. (2012), etc.

The problems of life-long learning for people with disabilities are of increasing concern to society, so many studies are being conducted in this aspect, and ways of solving this problem are being considered. Laabidi et al. (2014), are working on developing and implementing technology to enable people with disabilities to receive continuing education. Cooper (2016) is looking for ways in which online learning can be made accessible to students with disabilities. Beaton (2019), has analyzed how distance learning can be used to enhance the skills of individuals with disabilities. Hayes \& Bulat (2020), developed a guide to inclusive education systems and policies for people with disabilities in low- and middle-income countries.

Despite the availability of information and communication technologies (ICT) in today's world, the daily creation of new applications that are actively used in educational activities (Ghavifekr et al., 2013; Schaper \& Pervan, 2007). Their use by people with disabilities can be the basis for their life-long learning and the acquisition of new knowledge and skills, which, in turn, allow them to master a particular profession or improve their professional skills. This article focuses on how ICTs can be used by people with disabilities for life-long learning and at different stages of learning.

\section{Materials and Methods}

Analysis of the relevant literature on the problem of introducing ICTs in the implementation of the principles of life-long learning for people with special needs.

\section{Results and Discussions}

\subsection{Results}

Informatization of society is a rapid process, which is determined by the active introduction of digital technologies in all spheres of human activity, in particular in the field of education (Sereda et al., 2019). Informatization of education is a process aimed at providing education with methodological and practical developments with optimal use of information and communication technologies in all areas of educational activity (Sartaeva, 2019; Aiqun, 2018; Kim \& Lee, 2011). The Law of Ukraine "On Education" notes that education is aimed at harmonious, comprehensive development of the individual as the highest value of society. It is noted that the development must take into account the physical and intellectual needs of the individual, his abilities, talents, and aspirations for self-development and self-realization.

Information and communication technologies in education - a set of methods and techniques of educational activities, providing for the use of digital technologies in educational activities to optimize the 
ways of transferring information (Bykov \& Ovcharuk, 2017; Dyshlieva, 2010; Morze \&Vorotnukova, 2016). "The National Doctrine of Education Development" defines as a priority direction of modern education not just the introduction of ICTs in the educational process, but also their active use in the implementation of mixed and distance forms of learning (Montequin et al., 2014; Sukmana et al., 2021).

Distance education, according to the Concept of Distance Education Development in Ukraine, is one of the forms of education, which is considered equivalent to full-time, part-time, evening classes. The implementation of distance education is possible with the use of distance learning technologies and ICT technologies. Blended learning is a form of education, which combines the basic components of distance and "traditional" education in those proportions that are appropriate for a particular situation. "Traditional" or face-to-face learning systems can fully correct the shortcomings of distance learning, while distance learning eliminates the possibility of eye problems (Murashchenko, 2017).

A separate form of training is training with the use of mobile technology - m-learning. This technology is based on the use of the mobile devices capabilities during the acquisition of a certain set of knowledge and the formation of elementary skills of working with search information systems and the world information network (Alsaadat, 2020). Both full and blended, and mobile learning technologies are available only when ICTs are used in the educational process. The listed forms of education opened several opportunities for education applicants associated with the advantages of these forms:

- access to learning materials at any time convenient for the education seeker;

- no ties to the classroom and no need to visit the educational institution;

- the opportunity to communicate in virtual space through e-mail correspondence, SMS, or during online conferences (Rahman, 2014; Kumar, 2016; Kalita \& Das, 2015).

The introduction of ICT technology in educational activities has not only changed the approach to the system of information exchange in the learning process, but also opened new horizons for people whose opportunities and time are limited, but the desire to learn and develop prevails over the disadvantages they have. Improvement of digital technologies, the growing popularity of mobile devices, and certain mobile applications provided the formation and development of such a form of education as continuous.

There is no unified definition of life-long learning, but many terms are actively used, which are considered synonymous to this concept: "adult education", "continuing education" (life-long learning), "further education", and " recurrent education". In the case when they talk about life-long learning, note its relevance during professional growth without discontinuing production, so it is also appropriate to use such phrases as: "permanent education", or "life-long education" (Ozdamli \& Ozdal, 2015; Bidokht \& Assareh, 2011). Each of the proposed concepts has its characteristic, specific distinction, but they are all similar, similar in that they characterize education as an incomplete process, is relevant for every adult (Salo, 2017).

For the first time, continuous education was talked about in the 1960s, and as a basic principle of education reform, it was defined in 1974 at the Council of UNESCO, which led to the formation of the Concept of Continuing Education. This concept is aimed at defining the individual as the center of civilization development, its continuous development and improvement should be carried out continuously, which will lead to the possibility of adaptation to the society, which is constantly transforming.

The traditional form of education is available to schoolchildren and students. It is aimed at obtaining basic knowledge, based on which a person chooses a profession, and, in the future, masters it through profile training. The acquired set of knowledge is fully implemented in professional activities, but later it is not enough, so the person continues learning throughout life, increasing the level of professional education, moving up the career ladder.

The educational process of people with special needs has its characteristic differences, which are determined not only by the formation of an inclusive educational space but also by an individual approach to the learning process. People with developmental disabilities can be grouped into four main groups:

- people with physical disabilities related to movement (limited limb movements, or reduced control over the movements of the arms and legs);

- people with visual impairments (blindness, partial loss of vision, color blindness);

Savinova, N., Berehova, M., Yanchytska, K., Stelmah, N., Biliuk, O., \& Kasatkina-Kubyshkina, O. (2021). ICT role during COVID-19 pandemic in lifelong learning for disabilities. International Journal of Health Sciences, 5(3), 594604. https://doi.org/10.53730/ijhs.v5n3.2572 
- people with hearing disabilities (deaf, partially deaf);

- people with cognitive defects.

According to the Law of Ukraine "On Education", in regards to developmental defects, all people have the right to receive a quality education, but the UNESCO Global Report (2013) noted that not all children with disabilities receive basic education. Through the obstacles that arise both in the process of learning activities, later there is a problem with obtaining vocational education, mastering a profession, and finding a job. Inclusive education is a complex of educational services aimed at ensuring the basic right of children with special needs to receive education at the place of residence in a general education institution. Inclusive education requires the formation of an inclusive educational environment and adaptation of educational institutions with the needs of education applicants who study there (Mishchyk, 2012; Sofija \& Ivan, 2018).

In Ukraine, all children with special needs have the opportunity to attend general educational institutions and receive education individually, taking into account their basic needs, which require adaptation of the program material per the needs of each child. Teachers working with such children receive additional training enabling them to carry out the educational process in a high-quality manner.

Informatization of society and the educational process also concerns children with special needs, it requires teachers to create an informative inclusive environment. The informative inclusive environment involves the use of ICT in educational activities and the development of digital competence in children with special needs.

The formation of an informative and inclusive environment is possible through the use of ICT tools and assistive technologies. Assistive technologies include tools, additional equipment, or software that allow people with disabilities to use a computer or mobile device in learning activities (Boyle et al., 2020; Domingo, 2012). Assistive technologies greatly simplify the process of accessing information and make it accessible for disabled people. Additional assistive technologies include:

- screen-reading software (an additional element that allows you to add a soundtrack to the text that is played, the ability to simulate mouse movements with the keyboard);

- software to enlarge the image on the screen;

- Braille display (a display that displays Braille characters);

- alternative means for entering information (on-screen keyboard, audio recording, and microphone input);

- keyboard enhancements (such as StickKeys, Mousekeys, repeatKeys, SlowKeys, BounceKeys, or ToggleKeys), mnemonics, key combinations;

- alternative devices that allow you to follow the text (Arrigo, 2005).

Studies by Duque et al. (2020), indicate that the use of ICT in an inclusive educational environment has a positive impact on children's development, and if they develop information and communication competence, they can learn continuously throughout their lives. The use of ICT in an inclusive educational environment can be done in three ways:

- for compensatory purposes (as technical support before the lesson, allows partially compensating or replacing lost or missing functions);

- for communication purposes (additional software and additional assistive technologies allow the use of ICT as an additional means of communication and significantly simplify the process of communication)

- with the didactic purpose (meeting individual needs of the child through differentiation of learning materials and simplification of the process of learning activities) (Zaporozhchenko, 2013).

Increased attention to the use of ICT in the formation of an inclusive educational space allowed not only to create an educational environment favorable for children with disabilities but also ensured the possibility of their further education in institutions of higher profile education, allowing for life-long learning. The formation of digital competence in school education allows further use of ICT as an effective tool for acquiring new knowledge. Depending on the complexity of developmental defects, a person can choose individual, blended, or distance learning (Gomez et al., 2020). 
Depending on what developmental defects a person has, having a basic level of knowledge, independently installs additional tools on the digital tools, greatly simplifies the learning process, and allows you to process information available to all users of the world wide web (Kusumajaya, 2021). Formed skills are constantly improving, so as the level of education of a person with special needs increases, her ICT skills improve. The desire for self-development necessitates the development of new skills and new knowledge, and for people with disabilities, self-development using ICT can be carried out in the following areas:

- improving one's ICT skills

- acquiring new knowledge by processing the materials available on the world information network;

- acquiring new skills through specialized applications;

- learning foreign languages with the help of special applications or special software (Páscoa \& Gil, 2014; Zaporozhchenko, 2013).

\subsection{Discussions}

A review of the literature shows that in today's information society it is impossible to live without formed information and communication (digital) competence. Formation of ICT skills and, consequently, digital competence takes place in the course of general education learning activities, but in the case of teaching children with special needs, this process has several peculiarities (Hussin et al., 2021; Widana et al., 2021). An ordinary child has access to ICT tools of childhood and actively learns to use them in the process of learning and cognitive activities. Using ICT in lessons and for recreational activities is normal for her, while a child with special needs may be limited in these activities. The analysis showed that children, later adults, with developmental disabilities can be grouped into four basic groups. Taking into account their developmental disabilities, the use of ICT must be implemented in a specific way.

For example, children (people) who have physical disabilities and movement disabilities require additional tools to facilitate information retrieval, processing, and presentation of results. Examples include decreased sensitivity of a computer mouse, use of a specialized keyboard, etc. On the other hand, such people may actively use ICT to view photos and videos, listen to audio files, etc.

In case people have problems with visual impairment, it is optimal to use tools that allow the display of Braille. If the person has low vision, then it is advisable to use applications that allow zooming in and analyzing the image at that level. In cases of color blindness, applications and programs can be used to greatly simplify the mechanism of perception of information by color blind people. Despite the disadvantages of vision, people with this group of limitations can use ICT to play audio files, use them for active communication using a microphone, etc. With hearing impairments, ICTs can process huge amounts of visualized material, transmit information during correspondence, or use specialized applications that allow communication via typed text. Having cognitive defects, in most cases, a person can master ICT skills, but the process is longer and slower.

After acquiring basic knowledge and having a basic level of established digital competence, people with disabilities can continue learning. Thus, using ICT a person can get a specialized education remotely or in a mixed form, without leaving the place of residence, if there is no such an opportunity. Obtaining specialized education can be only a starting point in the educational activities of a person with disabilities because using mobile technology, ICT, and specialized applications, the person can improve speech skills, learn foreign languages, raise his/her level of professional skills even without leaving home. Thus, ICT is a tool that allows anyone to learn continuously throughout life.

\section{Conclusion}

Information and communication technology is a component of educational activity that allows a person to learn throughout life. The digital competence developed during general education allows a person to improve and develop throughout life through the use of ICT, thus realizing life-long learning. People with special educational needs for their disabilities, just like normal children, receive basic knowledge of ICT use during

Savinova, N., Berehova, M., Yanchytska, K., Stelmah, N., Biliuk, O., \& Kasatkina-Kubyshkina, O. (2021). ICT role during COVID-19 pandemic in lifelong learning for disabilities. International Journal of Health Sciences, 5(3), 594604. https://doi.org/10.53730/ijhs.v5n3.2572 
their schooling in a general education institution, but unlike normal children, their use of ICT is possible only with the use of additional technical or software tools. With a basic knowledge and a basic level of digital competence, people with disabilities can continue their education using forms such as distance, blended or mobile learning. Using this approach to educational activities, people with disabilities have the opportunity not only to receive specialized education but also to realize themselves in a particular profession, grow professionally through continuous learning, move up the career ladder.

\section{Acknowledgments}

We are grateful to two anonymous reviewers for their valuable comments on the earlier version of this paper. 


\section{References}

Aiqun, Z. (2018). An IT Capability Approach to Informatization Construction of Higer Education Institutions. Procedia computer science, 131, 683-690. https://doi.org/10.1016/j.procs.2018.04.312

Alsaadat, K. (2010). Mobile learning technologies. In Global Learn (pp. 159-163). Association for the Advancement of Computing in Education (AACE).

Arrigo, M. (2005). E-learning accessibility for blind students. Recent Research Developments in Learning Technologies.

Bak, M. (2014). Neperervnist informatsiinoho suprovodu osvity [Continuity of information support of education]. Vyshcha osvita Ukrainy-Higher Education of Ukraine, 3, 50-57.

Beaton, C. (2019). Distance Learning as a Levelling Tool for People with Disabilities. In 2019 International Conference on Computational Science and Computational Intelligence (CSCI) (pp. 884-887). IEEE.

Bidokht, M. H., \& Assareh, A. (2011). Life-long learners through problem-based and self directed learning. Procedia Computer Science, 3, 1446-1453. https://doi.org/10.1016/j.procs.2011.01.028

Boyle, C. A., Fox, M. H., Havercamp, S. M., \& Zubler, J. (2020). The public health response to the COVID-19 pandemic for people with disabilities. Disability and Health Journal,13(3), 100943. https://doi.org/10.1016/j.dhjo.2020.100943

Brahim, H. B., Jemaa, A. B., Jemni, M., \& Laabidi, M. (2013). Towards the design of personalised accessible elearning environments. In 2013 IEEE 13th International Conference on Advanced Learning Technologies (pp. 419-420). IEEE.

Bykov, V. Y., \& Ovcharuk, O. V. (2017). Otsiniuvannia informatsiino-komunikatsiinoi kompetentnosti uchniv ta pedahohiv v umovakh yevrointehratsiinykh protsesiv v osviti. Kyiv: Pedahohichna dumka [in Ukrainian].

Cooper, M. (2006). Making online learning accessible to disabled students: an institutional case study. ALTJ, 14(1), 103-115.

Davydov, P. H. (2010). Bezperervna osvita-vymohy chasu chy nova filosofiia osvitnyoi diialnosti. Continuing Education-time requirements or new philosophy of educational activities]. Visnyk Donetskoho natsionalnoho universytetu ekonomiky i torhivli im. m. Tuhan-Baranovskoho. Seriia «Humanitarni nauky, (2), 170-175.

Díez-Palomar, J., Ocampo Castillo, M. D. S., Pascual, A. M., \& Oliver, E. (2021). Adults With Special Educational Needs Participating in Interactive Learning Environments in Adult Education: Educational, Social, and Personal Improvements. A Case Study. Frontiers in Psychology, 12, 1983.

Domingo, M. C. (2012). An overview of the Internet of Things for people with disabilities. journal of Network and Computer Applications, 35(2), 584-596. https://doi.org/10.1016/j.jnca.2011.10.015

Duque, E., Gairal, R., Molina, S., \& Roca, E. (2020). How the psychology of education contributes to research with a social impact on the education of students with special needs: the case of successful educational actions. Frontiers in psychology, 11, 439.

Dyshlieva, S. (2010). Informatsiino-komunikatsiini tekhnolohii (IKT) ta yikh rol v osvitnomu protsesi [An information and communication technologies (ICTs) and their role in the educational process]. Retrieved April, 2, 2020.

Ghavifekr, S., Afshari, M., Siraj, S., \& Seger, K. (2013). ICT application for administration and management: A conceptual review. Procedia-Social and Behavioral Sciences, 103, 1344-1351. https://doi.org/10.1016/j.sbspro.2013.10.705

Gomez, E., Azadi, J., \& Magid, D. (2020). Innovation born in isolation: Rapid transformation of an in-person medical student radiology elective to a remote learning experience during the COVID-19 pandemic. Academic radiology, 27(9), 1285-1290. https://doi.org/10.1016/j.acra.2020.06.001

Hayes, A. M., \& Bulat, J. (2020). Disabilities inclusive education systems and policies guide for low-and middleincome countries.

Hurevych, R. S., Kademiia, M. Y., \& Koziar, M. M. (2012). Informatsiino-komunikatsiini tekhnolohii v profesiinii osviti maibutnikh fakhivtsiv [Information and communication technologies in the professional education of future specialists]. Lviv: SPOLOM.

Hussin, D. A., Samah, M. A. A., Suhaimi, A. A., \& Kamarudin, M. K. A. (2021). A study on knowledge, attitude and practice of COVID-19 pandemic among the residents. International Journal of Health Sciences, 5(2), 177 188. https://doi.org/10.29332/ijhs.v5n2.1378

Savinova, N., Berehova, M., Yanchytska, K., Stelmah, N., Biliuk, O., \& Kasatkina-Kubyshkina, O. (2021). ICT role during COVID-19 pandemic in lifelong learning for disabilities. International Journal of Health Sciences, 5(3), 594604. https://doi.org/10.53730/ijhs.v5n3.2572 
Kalita, S., \& Das, S. (2015). Use of ICT in distance higher education with special reference to institute of distance and open learning of Gauhati university. Journal of Process Management. New Technologies, 3(3), 104-111.

Kavcic, A. (2005). Software accessibility: Recommendations and guidelines. In EUROCON 2005-The International Conference on" Computer as a Tool" (Vol. 2, pp. 1024-1027). IEEE.

Kim, J., \& Lee, W. (2011). An analysis of educational informatization level of students, teachers, and parents: In Korea. Computers \& Education, 56(3), 760-768. https://doi.org/10.1016/j.compedu.2010.10.018

Kumar, P. (2016). Advantages of information and communication technologies in distance, IJARIIE-ISSN(0)2395-43961. 2017, 2(1),10-15.

Kusumajaya, A. A. N. (2021). Individual and social environmental factor as risk factor of BMI-for-age in school children. International Journal of Health Sciences, 5(2), 89-98. https://doi.org/10.29332/ijhs.v5n2.1242

Laabidi, M., Jemni, M., Ayed, L. J. B., Brahim, H. B., \& Jemaa, A. B. (2014). Learning technologies for people with disabilities. Journal of King Saud University-Computer and Information Sciences, 26(1), 29-45. https://doi.org/10.1016/j.jksuci.2013.10.005

Laal, M. (2013). Lifelong learning and technology. Procedia-Social and Behavioral Sciences, 83, 980-984. https://doi.org/10.1016/j.sbspro.2013.06.182

London, M. (2012). Oxford Handbook of Life-long Learning (1st edn). Psychology, Organizational Psychology, School Psychology.

Mishchyk, L. I. (2012). Inkliuzyvna osvita yak umova sotsializatsii ditei-invalidiv u protsesi navchannia [Inclusive education as a condition for the socialization of children with disabilities in the learning process]. Zbirnyk naukovykh prats Khmelnytskoho instytutu sotsialnykh tekhnolohii Universytetu Ukraina [Collection of scientific works of Khmelnytsky Institute of Social Technologies of the University of Ukraine], 5, 139-142.

Montequin, V. R., Cousillas, S., Ortega, F., \& Villanueva, J. (2014). Analysis of the success factors and failure causes in Information \& Communication Technology (ICT) projects in Spain. Procedia Technology, 16, 992999. https://doi.org/10.1016/j.protcy.2014.10.053

Morse, N.V., \& Vorotnikov, I.P. (2016). ICT model of teacher competence. ScienceRise. Pedagogical Education, (10), 4-9.

Murashchenko, T.V. (2017). Zmishane ta dystantsiine navchannia yak sposib dostupu do yakisnoi osvity. Vidkryte osvitnie e-seredovyshche suchasnoho universytetu [Blended and distance learning as a way to access quality education]. Open educational e-environment of a modern university. 3,283-287.

Osadchyi, V. V., \& Osadcha, K. P. (2015). Suchasni realii i tendentsii rozvytku informatsiino-komunikatsiinykh tekhnolohii v osviti, Informatsiini tekhnolohii i zasoby navchannia. IsS, 48(4), 47-57.

Ozdamli, F., \& Ozdal, H. (2015). Life-long learning competence perceptions of the teachers and abilities in using information-communication technologies. Procedia-Social and Behavioral Sciences, 182, 718-725. https://doi.org/10.1016/j.sbspro.2015.04.819

Páscoa, G., \& Gil, H. (2014). Information and communication technologies and lifelong learning: A population study 50+. In 2014 9th Iberian Conference on Information Systems and Technologies (CISTI) (pp. 1-5). IEEE.

Peters, S. J. (2003). Inclusive education: Achieving education for all by including those with disabilities and special education needs. Washington, The World Bank.

Piekhota, O. M., Tykhonova, T. V., Velikhovska, A. B., Alilova, F. S., Zubenko, T. V., \& Zakhar, 0. H. (2013). Informatsiino-komunikatsiini tekhnolohii v pedahohichnii osviti: navchalnyi posibnyk. Mykolaiv: Ilion, 252.

Poroshenko, M. A. (2019). Inkliuzyvna osvita: navchalnyi posibnyk. Kyiv: TOV «Ahentstvo «Ukraina»[in Ukrainian].

Rahman, H. (2014). The role of ICT in open and distance education. Turkish Online Journal of Distance Education, 15(4), 162-169.

Salo, A.V. (2017). Bezperervna osvita yak priorytetnyi napriamok pidvyshchennia profesiinoi kompetentnosti fakhivtsiv [Continuing education as a priority area for improving the professional competence of specialists]. Efektyvna ekonomika. 3.

Sartaeva, N.T. (2019). Informatization of education. Informatization of society: socio-economic, socio-cultural and international aspects: materials of the IX international scientific conference on January 15-16, 2019. Prague: 30-31. Vědecko vydavatelské centrum «Sociosféra-CZ», 2019. 57 p. ISBN 978-80-7526-362-9 
Schaper, L. K., \& Pervan, G. P. (2007). ICT and OTs: A model of information and communication technology acceptance and utilisation by occupational therapists. International journal of medical informatics, 76, S212-S221. https://doi.org/10.1016/j.ijmedinf.2006.05.028

Sereda, I. V., Savinova, N. V., Stelmah, N. V., \& Biliuk, O. H. (2019). Rivni sformovanosti informatsiino komunikatsiinoi kompetentnosti pedahohiv zakladiv zahalnoi serednoi osvity [Levels of information and communication competence formation for educators in general educational institutions]. Informatsiini tekhnolohii i zasoby navchannia-Information Technologies and Learning Tools, 74(6), 56-70.

Shevchenko, L. S. (2017). Pidhotovka maibutnikh uchyteliv do innovatsiinoi pedahohichnoi diialnosti: kontekstnyi pidkhid [Future teachers training to innovative pedagogical activity: context approach]. Informatsiini tekhnolohii v osviti-Information Technologies in Education, 1(30), 180-190.

Sofija, G., \& Ivan, T. (2018). Quality of life in children with disabilities placed in foster families. International Journal of Health \& Medical Sciences, 1(1), 18-27.

Sukmana, M. E., Kristiyanto, A., \& Liskustyawati, H. (2021). The relationship between emotional intelligence and hardiness on stress resistance in athletes with disabilities in Indonesian national Paralympic committee . International Journal of Health \& Medical Sciences, 4(1), 23-37.

UNESCO (2019). 4th Global Report on Adult Learning and Education. Leave No One Behind: Participation, Equity and Inclusion.

UNICEF. (2014a). Global initiative on out-of-school children: South Asia regional study.

Vorozhbyt, A. V. (2018). Veb-oriientovane informatsiino-osvitnie seredovyshche zakladu osvity [Weboriented information and educational environment of the educational institution]. Informatsiini tekhnolohii v osviti-Information Technologies in Education, 3(36), 20-29.

Vuorikari, R., Punie, Y., Gomez, S. C., \& Van Den Brande, G. (2016). DigComp 2.0: The digital competence framework for citizens. Update phase 1: The conceptual reference model (No. JRC101254). Joint Research Centre (Seville site).

WHO (2020). Disability and health.

Widana, I.K., Sumetri, N.W., Sutapa, I.K., Suryasa, W. (2021). Anthropometric measures for better cardiovascular and musculoskeletal health. Computer Applications in Engineering Education, 29(3), 550561. https://doi.org/10.1002/cae.22202

Zaporozhchenko, YuH. (2013). Vykorystannia zasobiv IKT dlia pidvyshchennia yakosti inkliuzyvnoï osvity [Use of ICT resources to increase the quality of inclusive education]. Informatsiy̆ni tekhnolohiï v osviti: Zb. nauk. prats. Kherson: KhDU. 2013; 15:138-145.

Savinova, N., Berehova, M., Yanchytska, K., Stelmah, N., Biliuk, O., \& Kasatkina-Kubyshkina, O. (2021). ICT role during COVID-19 pandemic in lifelong learning for disabilities. International Journal of Health Sciences, 5(3), 594604. https://doi.org/10.53730/ijhs.v5n3.2572 


\section{Biography of Authors}

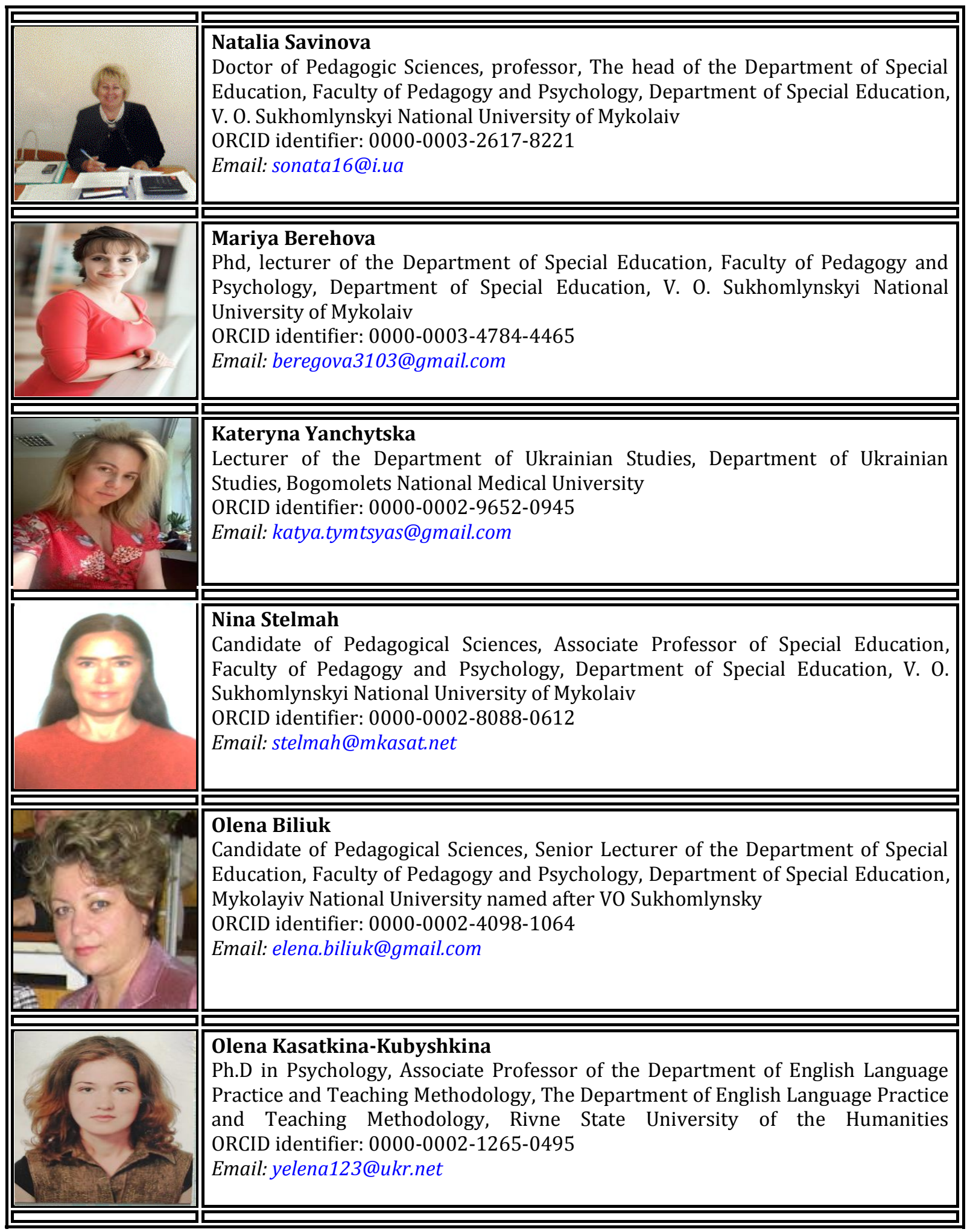

